\title{
DELAYED NEUROLOGICAL MATURATION IS A CAUSE FOR DISTRESS DURING FETAL GROWTH RESTRICTION
}

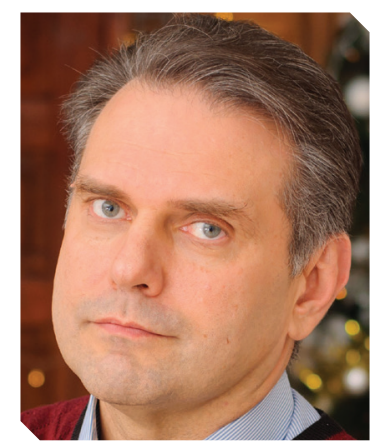

I.V. LAKHNO

MD, professor, Department of

Perinatology, Obstetrics and

Gynecology, Kharkiv Medical

Academy of Postgraduate

Education, Kharkiv

ORCID: 0000-0002-7914-7296

Researcher ID: E-7931-2016

\section{S.E. MALIKOVA}

assistant, Department of Perinatology, Obstetrics and Gynecology, Kharkiv Medical Academy of Postgraduate

Education, Kharkiv

ORCID: 0000-0001-9438-3484

\section{Contacts:}

IgorV. Lakhno

Kharkiv Medical Academy of

Postgraduate Education, Department

of Perinatology, Obstetrics and

Gynecology

Amosova str. 58

61176, Kharkiv, Ukraine

Tel.: +38 (057) 7119542

email: igorlakhn071@gmail.com

\section{INTRODUCTION}

Fetal growth and maturation critically depends on the placental function and captures all external impact from the maternal organism. Maturation of the autonomic nervous system demonstrates a fetal growing ability to provide ergotropic and trophotropic reactions. Any pathological stimulus may disturb fetal well-being. Theory of fetal programming explains how abnormal fetal status could have repercussions in the great number of diseases in a further [1,2].

Fetal growth restriction (FGR) is a convenient model for the investigation of abnormalities of fetal neurodevelopment $[3,4]$. Fetal heart rate variability (HRV) is a well-known approach for the detection of fetal autonomic function [5]. Results of several recent studies showed that variables of fetal HRV in FGR are disturbed [6, 7]. Amplitude of mode (AMo), stress index (SI) use in fetal distress detection was found $[8,9]$. AMo is a number of intervals corresponding to the mode value in $\%$ to the sample size. AMo and SI reflect the activity of sympathetic regulation [10]. Therefore the delayed maturation of autonomic nervous regulation could be a sensitive marker of FGR $[11,12]$. Non-invasive fetal electrocardiography (NI-FECG) is a prospective method for HRV-indices study. But it has some limitations. The issue is a growing layer of vernix caseosa in terms from 29 to 34 weeks. Good quality of NI-FECG tracing was found in the period of neurological maturation (24-28 weeks) $[13,14]$.

The aim of this study was to detect several patterns of autonomic nervous regulation in FGR complicated by fetal distress or without fetal distress.

\section{MATERIALS AND METHODS}

The study protocol was approved by the Bioethics Committee of the Kharkiv Medical Academy of Postgraduate Education (registration number 0116U002865). The eligible participants were informed about the study's methodology, its aims, objectives, indications and eventual complications before enrollment. Patients from the department of maternal-fetal medicine were selected randomly for the cross-sectional study. Totally 64 patients at 26-28 weeks of gestation were enrolled. FGR were detected in 41 women. 23 patients had normal fetal growth and were included in the Group I (control). 20 pregnant women with FGR wthout fetal distress were observed in Group II. 21 patients with FGR and fetal distress consists Group III.
The FGR was diagnosed if fetal weight parameters were lower than 10th percentile according to ultrasound. The reversed diastolic component in the umbilical artery (UA), absent a-wave in the ductus venosus (DV) and umbilical vein (UV) pulsation pulsations were the features of fetal distress [15-19].

The fetal HRV and conventional CTG patterns were obtained from RR-interval time series registered from maternal abdominal wall via NI-FECG. The equipment "Cardiolab Baby Card" (Scientific Research Center "KhAl-Medica", Ukraine) was used. Registration was carried out over 30-60 minutes. Total power (TP) and its spectral compounds i.e. very low frequency (VLF), low frequency (LF), high frequency (HF) and LF/HF ratio or sympatho-vagal balance was determined.

The temporal characteristics of the fetal HRV were calculated: standard deviation of normal to normal intervals (SDNN), root mean square of successive heartbeat interval differences (RMS$\mathrm{SD}$ ), proportion of the number of pairs of NNs differing by more than $50 \mathrm{~ms}$ divided by the total number of NNs (pNN50), AMo (the most frequent value of NN interval or the highest column in the histogramm) - the number of NN intervals included in the pocket corresponding to the mode measured in percentages (\%) and $\mathrm{SI}=\mathrm{AMo}(\%) /$ $(2 \times$ Mo $\times$ Var $) ; \operatorname{Var}=$ NNmax - NNmin [2-5].

Obtained fetal RR interval time series was transformed into CTG tracing. The following CTG parameters were determined: short term variation (STV), long term variation (LTV) and the number of accelerations and decelerations.

Results of the study were analyzed with an ANOVA test to compare data between groups. The significance was set at $p<0.05$. SPSS for Windows Release 19.0 (SPSS Inc. Chicago, Illinois, license No 15G09207000A) software was used for statistical analysis.

\section{RESULTS}

Suppression of the total level of HRV with sympathetic overactivity was found in FGR (Table). The reduced vagal activity according to the values of RMSSD and HF was detected. FGR was featured by a gradual decrease of TP with a maximal elevation of AMo and SI in fetal distress Group. The maximal growth of sympatho-vagal balance was found in Group III. Fetal deterioration was associated with an increased quantity of decelerations, reduced level of accelerations, and decreased of STV and LTV. 


\section{МІЖДИСЦИПЛІНАРНИЙ КОНСИЛІУМ}

Table. Fetal HRV parameters and CTG indices in the study population

\begin{tabular}{|c|c|c|c|}
\hline Index & Group I & Group II & Group III \\
\hline SDNN, ms & $42.1 \pm 6.1$ & $31.6 \pm 4.2^{*}$ & $11.5 \pm 2.6^{*, \dagger}$ \\
\hline RMSSD, ms & $21.1 \pm 2.8$ & $14.5 \pm 2.4^{*}$ & $8.0 \pm 0.6^{*,+}$ \\
\hline pNN50,\% & $4.1 \pm 0.5$ & $2.2 \pm 0.3^{*}$ & $1.2 \pm 0.2^{*, \dagger}$ \\
\hline $\mathrm{AMo}, \%$ & $38.2 \pm 6.0$ & $51.3 \pm 8.9^{*}$ & $62.8 \pm 5.6^{*, \dagger}$ \\
\hline Sl, c.u. & $660.5 \pm 81.2$ & $1068.3 \pm 152.8^{*}$ & $2825.1 \pm 403.5^{*, t}$ \\
\hline $\mathrm{TP}, \mathrm{ms}^{2}$ & $814.2 \pm 125.1$ & $643.7 \pm 88.4^{*}$ & $224.5 \pm 40.6^{*,+}$ \\
\hline$V L F, m s^{2}$ & $562.7 \pm 89.4$ & $401.0 \pm 56.3^{*}$ & $117.0 \pm 34.2^{*,+}$ \\
\hline $\mathrm{LF}_{\mathrm{F}} \mathrm{ms}^{2}$ & $151.8 \pm 44.6$ & $194.7 \pm 29.1^{*}$ & $90.1 \pm 11.4^{*, \dagger}$ \\
\hline$H F, \mathrm{~ms}^{2}$ & $100.6 \pm 9.4$ & $49.1 \pm 8.3^{*}$ & $16.8 \pm 3.5^{*, t}$ \\
\hline LF/HF & 1.5 & 4.0 & 5.4 \\
\hline STV, ms & $7.5 \pm 2.8$ & $6.0 \pm 2.2^{*}$ & $4.1 \pm 1.6^{*, \dagger}$ \\
\hline LTV, ms & $21.9 \pm 7.1$ & $16.1 \pm 5.8^{*}$ & $12.6 \pm 4.3^{*,+}$ \\
\hline $\begin{array}{l}\text { Number of } \\
\text { accelerations }\end{array}$ & $12.5 \pm 2.9$ & $9.9 \pm 0.8^{*}$ & $1.1 \pm 0.3^{*,+}$ \\
\hline $\begin{array}{l}\text { Number of } \\
\text { decelerations }\end{array}$ & $1.4 \pm 0.3$ & $8.5 \pm 2.3^{*}$ & $8.6 \pm 2.4^{*, \dagger}$ \\
\hline
\end{tabular}

We have found that each group of the study population has its own pattern of the autonomic nervous regulation and CTG curve. The samples are located below.

Case 1. A pregnant primigravida woman of 22 years was admitted to the Department of Feto-Maternal Medicine of Kharkiv Municipal Perinatal Center at the term of gestation 26 weeks. The prodromes of any maternal diseases before gestation were not found. Fisrt trimester biochemical tests were normal. She had mild pre-eclampsia and FGR. Fetal distress was diagnosed via Doppler ultrasound. The reversed diastolic component in the UA, absent a-wave in the DV and UV pulsations were found. The data of NI-FECG demonstrated the suppressed fetal autonomic tone with the decelerative pattern of beat-to-beat variations curve (an analog of the ultrasound cardiotocography curve) (Fig. 1). The decreased STV (2.6) supported the diagnosed fetal distress. The variables of HRV were abnormal. TP was decreased (92 $\left.\mathrm{ms}^{2}\right) . \mathrm{SI}=3102$ and $\mathrm{AMo}=85 \%$ were dramatically elevated.

The fetal demise occurred the next day. The labour was induced. Woman delivered a dead male baby of $460 \mathrm{~g}, 28 \mathrm{~cm}$ body length, and $20 \mathrm{~cm}$ head circumference.

Case 2. A primigravida woman aged 31 hospitalized to the Delivery Department because of the preterm rupture of fetal membrane at a term of 27 weeks of gestation. She had regular antenatal visits. No maternal diseases were known. The course of antimicrobial therapy and betamethasone ( $24 \mathrm{mg}$ ) was started. FGR and disturbed circulation in uterine arteries were detected via Doppler ultrasound. No more clinical or instrumental pathological findings were detected. Several accelerations and decelerations were found on the NI-FECG tracing (Fig. 2). Parameters of beat-to-beat variations were normal. Despite the revealed reactivity, the variable of TP was only $204 \mathrm{~ms}^{2}$. The variables of HRV markers of fetal distress were moderately elevated: $\mathrm{SI}=1135$ and $\mathrm{AMo}=74 \%$.

Regular uterine contractions started in 5 days. Woman delivered vaginally a female baby of $700 \mathrm{~g}, 30 \mathrm{~cm}$ length, $24 \mathrm{~cm}$ head circumference, and Apgar score $3 \rightarrow 5$. Baby passed to the Neonatal Resuscitation Unit and sent home in 74 days.

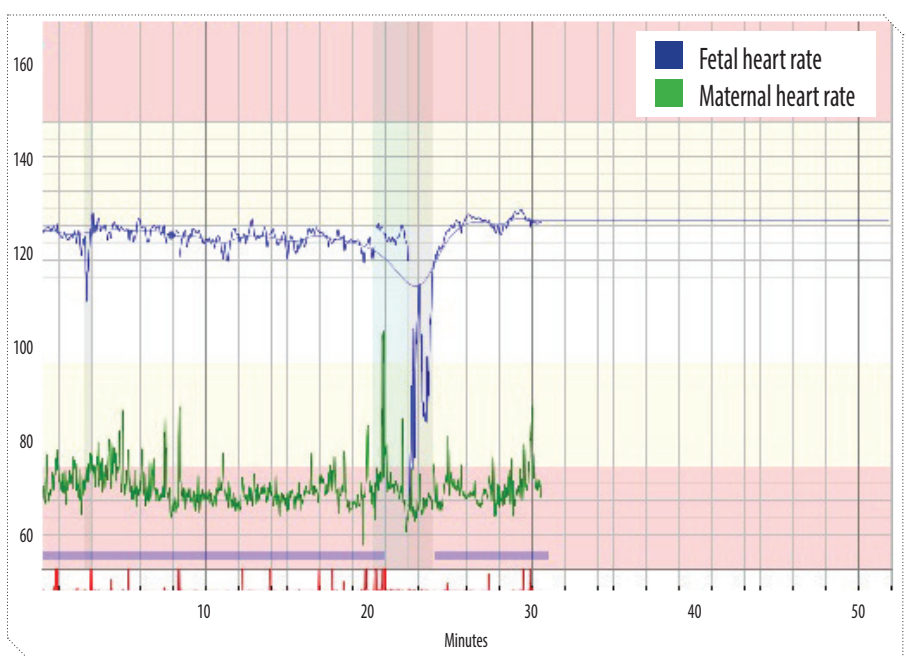

Figure 1. Tracing of beat-to-beat variations in a growth-restricted fetus

Blue line is fetal beat-to-beat variatiations curve and green one is maternal. Blue line crossing the fetal heart rate pattern shows the estimated basal heart rate (baseline). Gray shaded areas show the detected accelerations and decelerations.

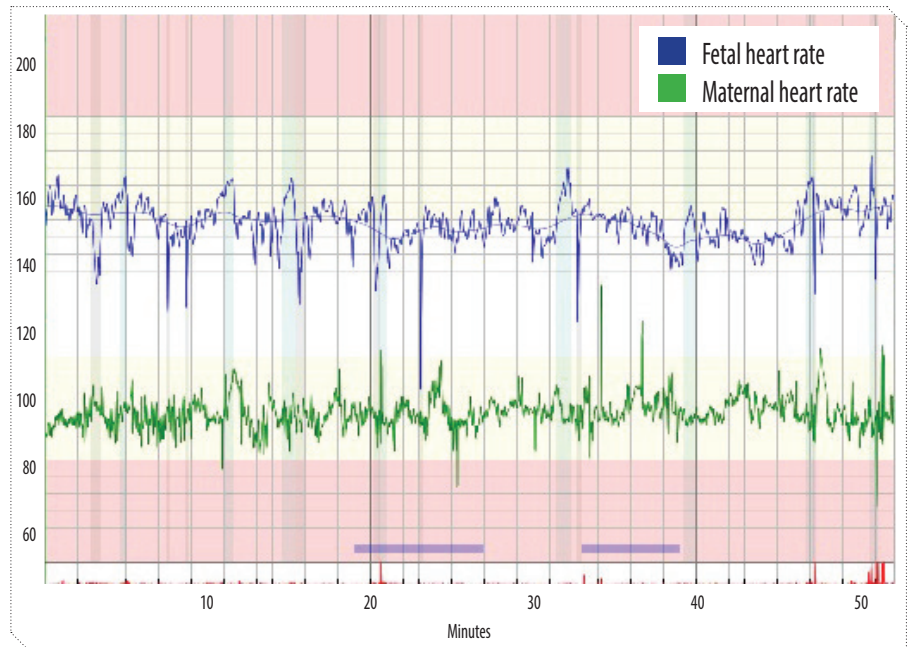

Figure 2. Tracing of beat-to-beat variations in a growth-restricted fetus with several accelerations and decelerations

Case 3. Pregnant woman aged 28 with the uterine scar was hospitalized to the Department of Feto-Maternal Medicine at 26 weeks of gestation. She had a pelvic fracture because of the traffic accident in her anamnesis. The short cervix $(15 \mathrm{~mm})$ was found via ultrasound. Obstetric pessary was inserted. Hemodynamic Doppler ultrasound showed the increased vascular resistance in uterine arteries and elevated systolic/diastolic ratio in the middle cerebral artery. The pattern of fetal beat-to-beat variations obtained by NI-FECG was reactive (Fig. 3). HRV parameters were absolutely normal: $\mathrm{TP}=825 \mathrm{~ms}^{2} ; \mathrm{SI}=651 ; \mathrm{AMo}=65 \%$.

Unfortunately, a preterm rupture of the fetal membrane occurred at 29 weeks of gestation. Baby of $810 \mathrm{~g}, 33 \mathrm{~cm}$ length, 24 $\mathrm{cm}$ head circumference, and Apgar score $5 \rightarrow 6$ was delivered via caesarean. Baby passed to the Neonatal Resuscitation Unit and sent home in 44 days.

\section{DISCUSSION}

Management of pregnant women with an early-onset FGR is still an issue. Besides well-known hemodynamic Doppler findings, presence of decelerations and decreased beat-tobeat variations are the markers of fetal distress [20-24]. But a 


\section{МІЖДИСЦИПЛІНАРНИЙ КОНСИЛІУМ}

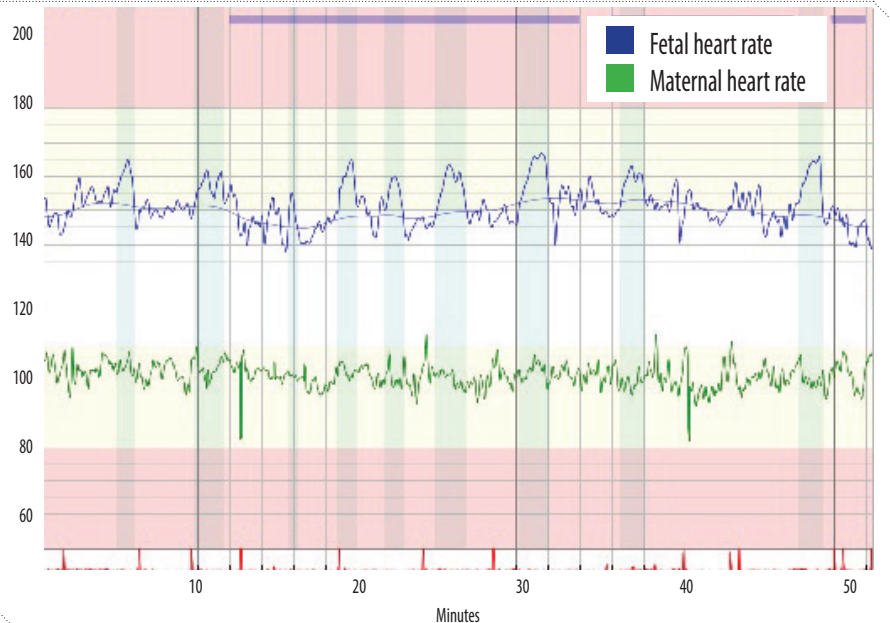

Figure 3. The reactive pattern of the tracing of beat-to-beat variations in a growthrestricted fetus

decelerative pattern before 26 weeks of gestation is normal. Just after this term fetal autonomic regulation starts to be reactive to its motility by increasing heart rate [2]. The speculation that delayed neurological maturation is a reason for the fetal distress in FGR was done. Revealed markers of the suppressed autonomic nervous regulation and sympathetic overactivity were detected in FGR.
The first case demonstrates that fetal autonomic malfunction and heart rate decelerations were the predictors of antenatal fetal death. The persisted decelerations with accelerations were the signs of mild fetal deterioration because of chronic placental insufficiency in the second case. No markers of fetal distress and normal reactivity were found in the third case. Therefore fetal autonomic malfunction could be a result of the persistent neurological immaturity in FGR.

NI-FECG is a prospective method for fetal monitoring besides some methodological problems [25]. Temporal resolution of this method is satisfactory for the investigation of fetal HRV [13-14]. This study shows that the NI-FECG technique could support the diagnosing of fetal distress in FGR by detecting suppressed HRV and abnormal pattern of beat-to-beat variations. TP, AMo, and SI were good predictors of fetal deterioration in this study. The approach based on the monitoring of fetal autonomic maturity in the diagnosing of its well-being should be tested in further studies.

\section{CONCLUSION}

The fetal HRV variables and beat-to-beat variations parameters could be the sensitive markers of the neurological maturation and good predictors for fetal deterioration.

\section{REFERENCES/ЛІTЕPATУPA}

\section{Crespi, B.J.}

"Why and How Imprinted Genes Drive Fetal Programming."

Front Endocrinol (Lausanne) 10 (2020): 940.

2. Hoyer, D., Zebrowski, J., Cysarz, D., et al.

"Monitoring fetal maturation-objectives, techniques and indices of autonomic function." Physiol Meas 38 (2017): 61-88.

3. Hoyer, D., Kowalski, E.M., Schmidt, A., et al.

"Fetal autonomic brain age scores, segmented heart rate variability analysis, and traditional short term variability."Front Hum Neurosci 8 (2014): 948.

4. Hoyer, D., Tetschke, F., Jaekel, S., et al.

"Fetal functional brain age assessed from universal developmental indices obtained from neuro-vegetative activity patterns." PloS One 8 (2013): e74431.

5. Hoyer, D., Schmidt, A., Gustafson, K.M., et al.

"Heart rate variability categories of fluctuation amplitude and complexity: diagnostic markers of fetal development and its disturbances." Physiol Meas 40.6 (2019): 064002.

6. Velayo, C.L., Funamoto, K., Silao, J.N., et al.

"Evaluation of Abdominal Fetal Electrocardiography in Early Intrauterine Growth Restriction." Front Physiol 8 (2017): 437.

\section{Lakhno,l.}

"Fetal non-invasive electrocardiography contributes to better diagnostics of fetal distress: a cross-sectional study among patients with preeclampsia." Annals of the Academy of Medicine Singapore 44.11 (2015): 519-23.

8. Arias-Ortega, R., Echeverria, J.C., Gusman-Huerta, M., et al. "Respiratory sinus arrhythmia in growth restricted fetuses with normal Doppler hemodynamic indices." Early Hum Dev 93

(2015): $17-26$

9. Guzman-Velazquez, P., Lakhno, I.V., Diaz-Mendez, A. "HRV Descriptors for Fetal Distress Assessment in Pregnancy with Fetal Growth Restriction." In: Proceedings of the 2018 International Conference on Biomedical Engineering \& Science BIOENG'18. CSREA Press (2018): 13-7.
10. May, L.E., Scholtz, S.A., Suminski, R., Gustafson, K.M. "Aerobic exercise during pregnancy influences infant heart rate variability at one month of age." Early Human Development 90.1 (2014): 33-8.

11. May, L.E., Suminski, R.R., Langaker, M.D., et al. "Regular maternal exercise dose and fetal heart outcome." Medicine and science in sports and exercise 44.7 (2012): $1252-8$

12. DiPietro, J., Kivlighan, K., Costigan, K., et al.

"Prenatal antecedents of newborn neurological maturation." Child Dev 81 (2010): 115-30.

13. Behar, J., Andreotti, F., Zaunseder, S., et al. "A practical guide to non-invasive foetal electrocardiogram extraction and analysis." Physiol meas 37 (2016): R1-R35.

14. Ashwal, E., Shinar, S., Aviram, A., et al.

"A novel modality for intrapartum fetal heart rate monitoring." Matern Fetal Neonatal Med 32.6 (2019): 889-95.

15. Hernandez Castro, R., Spiel, M.

"Early Fetal Growth Restriction." Neoreviews 21.3 (2020): e203-e209.

16. Frusca, T., Todros, T., Lees, C., Bilardo, C.M.; TRUFFLE Investigators.

"Outcome in early-onset fetal growth restriction is best combining computerized fetal heart rate analysis with ductus venosus Doppler: insights from the Trial of Umbilical and Fetal Flow in Europe."Am J Obstet Gynecol 218.2S (2018): S783-S789.

17. Monier, I., Ancel, P.Y., Ego, A., et al.

"Gestational age at diagnosis of early-onset fetal growth restriction and impact on management and survival: a population-based cohort study." BJOG 124.12 (2017): 1899-906.

18. Miescu, M., Carbunaru, O., Constantin, C., et al.

"Importance of Follow-Up and Early Detailed Evaluation in Early Onset Growth Restricted Fetuses." Curr Health Sci J 45.3 (2019): 333-8.
19. American College of Obstetricians and Gynecologycts. "ACOG Practice Bulletin No. 204: Fetal Growth Restriction." Obstet Gynecol 133.2 (2019): e97-e109.

20. Graatsma, E.M., Mulder, E.J.H., Vasak, B., Visser, H.A. "Average acceleration and deceleration capacity of the fetal heart rate in normal pregnancy and in pregnancies complicated by fetal growth restriction." J Matern Fetal Neonatal Med 25/12 (2012): 2517-22.

21. Nardozza, L.M., Caetano, A.C., Zamarian, A.C., et al. "Fetal growth restriction: current knowledge." Arch Gynecol Obstet 295.5 (2017): 1061-77.

22. Dall'Asta, A., Brunelli, V., Prefumo, F., et al.

"Early onset fetal growth restriction." Matern Health Neonatol Perinatol 3 (2017): 2

23. Aziz, W., Schlindwein, F.S., Wailoo, M., et al.

"Heart rate variability analysis of normal and growth restricted children." Clin Auton Res 22.2 (2012): 91-7.

\section{Sholapurkar, S.L.}

"Is fetal heart rate'deceleration area' the silver bullet for detection of acidemia?" Am J Obstet Gynecol 219.5 (2018): 510-2.

25. Mannella, P., Billeci, L., Giannini, A., et al.

"Feasibility study on non-invasive fetal ECG to evaluate prenatal autonomic nervous system activity." Eur J Obstet Gynecol Reprod Biol 246 (2020): 60-6. 


\section{МІЖДИСЦИПЛІНАРНИЙ КОНСИЛІУМ}

\section{DELAYED NEUROLOGICAL MATURATION IS A CAUSE FOR DISTRESS DURING FETAL GROWTH RESTRICTION}

I.V. Lakhno, MD, professor, Department of Perinatology, Obstetrics and Gynecology, KhMAPE, Kharkiv, Ukraine

S.E. Malikova, assistant, Department of Perinatology, Obstetrics and Gynecology, KhMAPE, Kharkiv, Ukraine

Theory of fetal programming contributes to a better understanding of the relationship of many human diseases with antenatal period pathology. Regulatory impact of nervous system is of great importance. Fetal growth restriction (FGR) is a convenient model for investigation of the abnormalities of fetal neurodevelopment. Fetal heart rate variability is a well-known approach for fetal autonomic function detection.

The aim of the study was to detect several patterns of autonomic nervous regulation in FGR complicated by fetal distress or without fetal distress.

Materials and methods. Totally 64 patients at 26-28 weeks of gestation were enrolled. 23 patients had normal fetal growth and were included in the Group I (control). 20 pregnant women with FGR without fetal distress were observed in Group II. 21 patients with FGR and fetal distress were included in Group III. Fetal heart rate variability and conventional cardiotocographic patterns were obtained from the RR-interval time series registered from the maternal abdominal wall via non-invasive fetal electrocardiography.

Results. Suppression of the total level of heart rate variability with sympathetic overactivity was found in FGR. The maximal growth of sympathovagal balance was found in Group III. Fetal deterioration was associated with an increased quantity of decelerations, reduced level of accelerations, and decreased of short term variations and low term variations. But a decelerative pattern before 26 weeks of gestation was normal. Therefore fetal autonomic malfunction could be a result of persistent neurological immaturity in FGR. The approach based on the monitoring of fetal autonomic maturity in the diagnosing of its well-being should be tested in further studies.

Conclusion. Fetal heart rate variability variables and beat-to-beat variations parameters could be the sensitive markers of neurological maturation and good predictors for fetal deterioration.

Keywords: fetal distress, fetal growth restriction, fetal non-invasive electrocardiography, neurodevelopment.

\section{СПОВІЛЬНЕНЕ ДОЗРІВАННЯ НЕРВОВОЇ СИСТЕМИ - ПРИЧИНА ДИСТРЕСУ ПРИ ЗАТРИМЦІ РОСТА ПЛОДА}

І.В. Лахно, Д. мед. н., професор кафедри перинатології, акушерства і гінекології ХМАПО, м. Харків

С.Е. Малікова, асистент кафедри перинатології, акушерства і гінекології ХМАПО, м. Харків

Теорія плодового програмування дозволяє пояснити взаємозв'язок багатьох захворювань людини з патологією антенатального періоду. Велике значення має регуляторний Вплив з боку нервової системи. Затримка росту плода (ЗРП) є зручною моделлю для дослідження порушень розвитку його нервової системи. Варіабельність серцевого ритму плода - добре відомий підхід для вивчення його вегетативної функції.

Мета дослідження. Встановити декілька типів вегетативної нервової регуляції при ЗРП, ускладненій дистресом або без дистресу плода.

Матеріали і методи. Усього було обстежено 64 пацієнтки в термінах гестації 26-28 тижнів. У 23 пацієнток було відмічено нормальне зростання плода. Вони були включені до групи I (контроль). У II групі під спостереженням перебувало 20 вагітних із ЗРП без дистресу плода, у III групі - 21 пацієнтка із ЗРП та дистресом плода. Варіабельність серцевого ритму плода та кардіотокографічні записи були отримані шляхом обробки тривалості інтервалів RR, зареєстрованих із черевної стінки матері за допомогою неінвазивної електрокардіографії плода.

Результати. Пригнічення загального рівня варіабельності серцевого ритму із підвищенням симпатичної активності було виявлено при ЗРП. Максимальне зростання симпатовагального балансу було виявлено у III групі. Погіршення стану плода було пов'язане зі збільшенням кількості децелерацій, зниженим рівнем акцелерацій та зменшенням значень короткотривалих та довготривалих коливань частоти серцевих скорочень. Але до 26 тижня вагітності наявність децелерацій є нормальним явищем. Тому порушення вегетативної функції плода може бути наслідком неврологічної незрілості при ЗРП. Підхід, заснований на спостереженні за дозріванням нервової регуляції плода для діагностики його стану, повинен бути перевірений у подальших дослідженнях.

Висновок. Показники варіабельності серцевого ритму плода і параметри «удар до удару» варіацій можуть бути чутливими ознаками неврологічного дозрівання та маркерами погіршення стану плода.

Ключові слова: дистрес плода, затримка росту плода, неінвазивна електрокардіографія плода, розвиток нервової системи.

\section{ЗАМЕДЛЕННОЕ СОЗРЕВАНИЕ НЕРВНОЙ СИСТЕМЫ - ПРИЧИНА ДИСТРЕССА ПРИ ЗАДЕРЖККЕ РОСТА ПЛОДА}

И.В. Лахно, Д. мед. н., профессор кафедры перинатологии, акушерства и гинекологии ХМАПО, г. Харьков

С.Э. Маликова, ассистент кафедры перинатологии, акушерства и гинекологии ХМАПО, г. Харьков

Теория плодового программирования позволяет обьяснить взаимосвязь многих заболеваний человека с патологией антенатального периода. Большое значение имеет регуляторное влияние со стороны нервной системы. Задержка роста плода (ЗРП) является удобной моделью для исследования нарушений развития его нервной системы. Вариабельность сердечного ритма плода - хорошо известный подход для изучения его вегетативной функции.

Цель исследования. Установить несколько типов вегетативной нервной регуляции при ЗРП, осложненной дистрессом или без дистресса плода.

Материалы и методы. Всего были обследованы 64 пациентки в сроках гестации 26-28 недель. У 23 пациенток был отмечен нормальный рост плода. Они были включены В группу I (контроль). Во второй группе под наблюдением находились 20 беременных с зРП без дистресса плода, в третьей группе - 21 пациентка с 3 РП и дистрессом плода. Вариабельность сердечного ритма плода и кардиотокографические записи были получены путем обработки длительности интервалов RR, зарегистрированных с брюшной стенки матери с помощью неинвазивной электрокардиографии плода.

Результаты. Угнетение общего уровня вариабельности сердечного ритма с повышением симпатической активности было обнаружено при ЗРП. Максимальный рост симпатовагального баланса был обнаружен в III группе. Ухудшение состояния плода было связано с увеличением количества децелераций, пониженным уровнем акцелераций и уменьшением значений краткосрочных и долгосрочных колебаний частоты сердечных сокращений. Но до 26 недели беременности наличие децелераций нормальное явление. Поэтому нарушение вегетативной функции плода может быть следствием неврологической незрелости при ЗРП. Подход, основанный на наблюдении за созреванием нервной регуляции плода для диагностики его состояния, должен быть проверен в дальнейших исследованиях.

Вывод. Показатели вариабельности сердечного ритма плода и параметры «удар в удар» вариаций могут быть чувствительными признаками неврологического созревания и маркерами ухудшения состояния плода.

Ключевые слова: дистресс плода, задержка роста плода, неинвазивная электрокардиография плода, развитие нервной системы. 